\title{
[6]
}

\section{When Equal Is Not the Same}

"Reverse discrimination," "affirmative action," "preferential hiring," "preferential admissions"-all of these phrases somehow belong to the I970s. They predated that decade-"affirmative action," for example, appears in the Civil Rights Act of 1964-but it was then that the terms came into everyday use, as the policies they describe became matters of public concern. The terms are not always interchangeable. "Reverse discrimination" bears a negative connotation that has not yet attached to "affirmative action," which may be one reason why the latter phrase is more common in academic settings. But all of these policies have one thing in common: they favor members of groups that have previously been the objects of prejudice and invidious discrimination. The factor that differentiates these groups from the "majority" is usually race or ethnicity, and, less often, sex.

There is no strong societal agreement that such compensatory discrimination is ever justified. Even people who generally support it dispute such matters as what agencies may impose it, under what circumstances, and by what means, just as they dispute whether or not particular groups qualify for such treatment. But there is threshold agreement about what the terms mean and just whom we are discussing. That such agreement exists is a revealing fact about American society. Speaking of "reverse" discrimination can be meaningful only when "direct" discrimination has existed, only because "American society is currently a racially conscious society; this is the inevitable and evident consequence of a history of slavery, repression, and prejudice." 1

${ }^{1}$ Ronald Dworkin, "Why Bakke Has No Case," New York Review of Books, November 10, 1977, pp. I I. 
I have stated that no consensus exists about the legitimacy of these policies, which I shall lump together here as "reverse discrimination." Nor is there agreement about their constitutionality. The Supreme Court is still struggling toward a resolution of these problems. There are some "boundary" cases. A series of federal court decisions have established that racial discrimination is permissible when it is designed to rectify deliberate and documented past discrimination, for instance in public education or employment. ${ }^{2}$ One decision where the Supreme Court unanimously overturned a policy of reverse discrimination was $M c D o n a l d v$. Sante Fe Transportation Company, where an employer had discharged two white workers for misappropriating cargo but retained a black worker who had committed the same offense. ${ }^{3}$ So we know that one kind of reverse discrimination is permitted and may even be required, that which redresses past racial discrimination, while another kind is forbidden, namely, different punishments for the same act. But the major cases have fallen within these boundaries.

The first two cases, De Funis v. Odegaard and University of California Regents v. Bakke, had several features in common. ${ }^{4}$ Each involved admission to a graduate program in a state university, De Funis to law school and Bakke to medical school. The University of Washington's law school had established a scheme whereby all applicants were ranked according to a predicted first-year average (PFYA) on the basis of their grades and test scores. In 1971, the year Marco de Funis first applied to the law school, applicants whose PFYA fell below 74.5 points (out of a possible Ioo) were summarily rejected, unless they were black, Chicano, American Indian, or Filipino. Applicants from these four groups got a special review that gave less weight to the average. As a result, some minority applicants with scores below this cutoff point were admitted.

De Funis, whose score was 76.23 , was rejected. He sued, alleging a violation of the equal-protection clause. The state trial court ruled in his favor and ordered his admission, so that he did enter the law school in September 1971. The University appealed and won in the state's highest court. De Funis then took his case to the Supreme Court. Because he had been admitted, and was in his last quarter by the time

\footnotetext{
${ }^{2}$ See, e.g., Swann v. Charlotte-Mecklenburg Board of Education, 402 U.S. I (I97I); Franks v. Bowman Transportation Co., 424 U.S. 747 (1976); Albemarle Paper Co. v. Moody, 422 U.S. 405 (1975); Carter v. Gallagher, 452 F. 2nd 315 (8th Circ. 1972).

${ }^{3} 427$ U.S. 273 (1976).

${ }_{4}^{4} 416$ U.S. 312 (1974); 438 U.S. 265 (1978).
} 
the Court heard oral argument (he ranked, incidentally, about the middle of his class), ${ }^{5}$ the Court dismissed the case as moot.

That action effectively postponed for four years a decision on the merits. Meanwhile, Allan Bakke, a thirty-three-year-old white engineer who had been rejected by several medical schools despite excellent grades, test scores, and recommendations, brought suit against the University of California. The medical school at Davis had reserved sixteen of the one hundred places in its entering class for blacks, American Indians, Chicanos, and Asian-Americans. This policy was not only reverse discrimination, but, to use a word that bore even worse connotations, a quota. The year Bakke was rejected, minority students who ranked below him were admitted. Bakke challenged his exclusion under both the equal-protection clause and Title VI of the Civil Rights Act of I964, which forbids racial discrimination in any program receiving federal funds.

He won his case, by a vote of 5 to 4 . Of the majority, four justicesBurger, Stewart, Rehnquist, and Stevens-based their votes on Title VI, while Justice Powell insisted that both this law and the equalprotection clause forbade a racial classification of this nature. Powell argued, however, that while reserving a specific number of seats for minority applicants was illegal, the university could take race into account in a less specific way. White, Blackmun, Brennan, and Marshall joined him on this point. They dissented from the ruling against the Davis scheme, arguing that neither the Fourteenth Amendment nor Title VI forbade it. ${ }^{6}$ Obviously, the issue had not yet been resolved. Bakke did not even indicate how the Court would have decided De Funis on the merits.

Steelworkers v. Weber, decided a year later, in 1979, was brought not under the Constitution but under Title VII of the 1964 law.7 This section forbade employers and labor unions to "discriminate ... because of . . . race." The Kaiser Aluminum Corporation and the United Steelworkers of America had agreed on an affirmative action plan that reserved half of the openings in craft-training programs for blacks. Brian Weber, a white production worker in Kaiser's Gramercy, Louisiana, plant, was excluded from such a program in favor of black workers with less seniority.

The Court ruled, 5 to 2, that Title VII did permit such plans. (Since private, not government, action was involved, the equal-protection

${ }^{5}$ Ginger, ed., De Funis v. Odegaard, "Transcript of Oral Argument," p. I 334.

${ }^{6} 438$ U.S. 265, 408-2 I (Stevens), 28 I-3 I5, 320 (Powell), 324-79 (Brennan), 387402 (Marshall), 402-8 (Blackmun).

${ }^{7} 443$ U.S. 193 (1979). 


\section{Equality under the Constitution}

clause was not controlling.) Justice Brennan's opinion for the majority, and Justice Rehnquist's dissent for himself and Chief Justice Burger, presented two conflicting interpretations of legislative history. ${ }^{8}$ Stewart, who had voted against the Davis admissions plan, voted to sustain this one, without opinion in both cases. Powell, who had attacked quotas in Bakke, did not participate in Weber; not did Justice Stevens.

A year later, Fullilove v. Klutznick sustained another quota. ${ }^{9}$ The Court ruled that a federal public works program that reserved ro percent of spending for minority-owned businesses was within Congress' enforcement powers under Section 5 of the Fourteenth Amendment. Burger, writing for a plurality of three, relied heavily on congressional findings of past discrimination. Powell joined this opinion, but wrote a concurrence distinguishing Fullilove from Bakke on just this basis. Brennan, Blackmun, and Marshall restated their views on the general acceptability of reverse discrimination. Stewart-who appeared to be moving away from reverse discrimination as steadily as Powell was moving toward it - wrote a dissent that strongly rejected all racial discrimination, invidious or benign. Stevens and Rehnquist also dissented.

Here, at some risk, is the prevailing doctrine on reverse discrimination. The Fourteenth Amendment gives Congress the power to enact reverse discrimination plans, including quotas, at least when prior disadvantage and direct discrimination exist. For at least one justice, the same amendment forbids state agencies to establish quotas, but permits them to consider race in some nebulous way. Title VII of the Civil Rights Act of 1964, whose language forbids employment discrimination based on race, does in fact allow employers and unions to discriminate in favor of blacks, even by setting quotas. But Title VI, whose language prohibits racial discrimination in programs receiving federal money, does prevent such programs from setting racial quotas. Out of all this legislative and judicial language emerges only one firm constitutional rule: Congress may establish reverse discrimination programs when evidence of prior discrimination and disadvantage exists. Whether any other government-imposed reverse discrimination is acceptable, and under what circumstances, is unclear.

I am concerned here with the constitutionality of these policies, not with their wisdom or their desirability. Therefore, I confine myself to arguments that have some bearing on constitutional issues. I am asking whether reverse discrimination is compatible with the right to equal

\footnotetext{
${ }^{8}$ Ibid., pp. 197-209 (Brennan), 219-55 (Rehnquist).

${ }^{9}$ Ioo S.Ct. 2758 (1980).
} 
respect and concern, and whether it can satisfy the rigors of constitutional reasoning.

\section{Qualifications, Merit, and "the Right to Be Judged as an Individual"}

There are several common arguments against such policies, which I discuss in what I think can be shown to be ascending order of importance. One objection is that reverse discrimination rewards the less qualified while depriving the more qualified. Allan Bakke's case produced many versions of this argument. As a constitutional principle, however, the point is weak.

There exists at present no constitutional right to be judged according to one's "qualifications." But is there a basis for recognizing such a right? It could be argued that the fundamental right to equal respect and concern entails the derivative right to be rewarded according to merit. I agree that there are certain narrowly defined situations, such as that in $M c$ Donald, in which such a right exists. But, in general, no such relationship between treatment as an equal and merit holds.

Why not? Well, why? Are we comfortable with the idea that merit should be the only, or the principal, basis for the distribution of benefits? What about need, for instance? Besides, what does "merit" mean? One reason that it is difficult to accept such a claim is that some of the terms used have confused and arbitrary meanings. What does it mean to say that a person merits, deserves, or has earned the privilege of going to medical school or being hired? Do any standards exist, other than those chosen by the decision makers?

The term "qualifications" has similar difficulties; there is an absence of agreement as to what qualifications are. ${ }^{10}$ To the extent that agreement exists about qualifications for medical school, for examplegrade point average, score on the Medical College Admission Test, and recommendations-this agreement is the product of arbitrary decisions to weigh these factors heavily, decisions made long ago without much thought and accepted ever since. It would be bold and foolhardy to interpret the Constitution as enacting such fragile constructs.

A related argument that may appear to have more substance is that an applicant should be judged "as an individual" and not as a member

\footnotetext{
${ }^{10}$ See, e.g., Regents v. Bakke, 438 U.S. 265, 305-15 (Powell), 403-4 (Blackmun); Joel Dreyfuss and Charles Lawrence III, The Bakke Case: The Politics of Inequality (New York: Harcourt Brace Jovanovich, 1979), chap. 6.
} 


\section{Equality under the Constitution}

of a group. ${ }^{11}$ This has become a popular argument, but on analysis it turns out to have defects. Kenneth Karst and Harold Horowitz have pointed out that "any equal protection claim turns out to be a claim made as a member of a group. Indeed, any claim based on a rule of law is a demand to be treated in the same manner as all other persons similarly situated. A claim to be treated on the basis of one's 'individual attributes' either is a disguised claim to be treated as a member of a group possessed of one or more specific attributes or it is unintelligible." Dworkin has suggested that any judgment must rely on generalizations about groups. For example, establishing a GPA cutoff point, as the University of Washington did, treats both those above and those below as members of a group who share that attribute. ${ }^{12}$

Any standard, by definition, classifies those judged by it. It is wrong to suggest that I am treated "as an individual" if I am judged on the basis of my teaching evaluations or the number of my publications, but "as a member of a group" if I am judged by race or sex. In fact, what a demand to be treated as an individual often means is simply a demand to be treated as the privileged group has been treated; within that group, judgments may or may not have been made on merit or qualifications, however defined.

This argument is often confused with the "qualifications" argument. Grades and test scores are described as "individual" attributes because they are earned by an individual; they are acquired characteristics, as opposed to ascribed and permanent characteristics, such as race and sex. Earned attributes do have a relationship to individual merit that race and sex do not have, but it is hard to see how they are more related to individuality. A grade point average belongs to an individual; we say, "She pulled a 4.0 last semester." But we also say, "She's black." Race and sex belong to individuals, too.

The fact that these arguments, with their defects, are frequently made-and with vehemence, particularly in conversation-indicates that this issue has touched some very sensitive nerves. But the objections to reverse discrimination do not rely only on such arguments as these. The crucial point has often been that it is race that is the basis for choice. And such a policy bears a heavy burden of justification. It faces a ready-made, and powerful, counterargument.

${ }^{11}$ This argument is discussed in Nathan Glazer, Affirmative Discrimination (New York: Basic Books, 1975), chap. 6.

${ }^{12}$ Karst and Horowitz, "Affirmative Action and Equal Protection," Virginia Law Review 60 (October 1974):955-74, 96I; Dworkin, "Why Bakke Has No Case," p. I4. See also Owen M. Fiss, "Groups and the Equal Protection Clause," Philosophy and Public Affairs 5 (Winter 1976): 107-77; Paul Brest, "In Defense of the Antidiscrimination Principle," Harvard Law Review 90 (November 1976): 1-54. 


\section{Race Discrimination: Principle or Interest?}

The lesson of the great decisions of the Supreme Court and the lesson of contemporary history have been the same for at least a generation: discrimination on the basis of race is illegal, immoral, unconstitutional, inherently wrong, and destructive of democratic society. Now this is to be unlearned and we are told that this is not a matter of fundamental principle, but only a matter of whose ox is gored. Those for whom racial equality was demanded are to be more equal than others. Having found support in the Constitution for equality, they now claim support for inequality under the same Constitution.

The foregoing paragraph is a passage from Alexander M. Bickel's last and posthumously published book, The Morality of Consent. ${ }^{13}$ It has been cited in at least three Supreme Court opinions. ${ }^{14}$ With characteristic clarity and eloquence, Professor Bickel has made a powerful case against reverse discrimination. The argument is a strong one, for it accuses the proponents of hypocrisy and of self-serving deviation from the "neutral principles" sought in constitutional adjudication. That racial or sexual or ethnic discrimination is wrong constitutes what Herbert Wechsler would call "grounds of adequate neutrality and generality ... transcending the immediate result that is achieved" in any given case. ${ }^{15}$ That racial or sexual or ethnic discrimination is wrong when it favors certain groups but right when it favors other groups appears to be the very opposite of such a principle.

But this appearance is deceptive. However appealing Bickel's statement is, it is wrong. First, the great decisions of the I950s and I960s did not depend on the principle that race discrimination is unconstitutional, although some of them did articulate it. Second, the last sentence of the last paragraph does not articulate the principle on which reverse discrimination depends. The distinction between invidious and benign discrimination-or, to phrase it differently, between traditional and reverse discrimination-is not simply a matter of whose ox is being gored. The argument for any given program may be made that way, but that, after all, is how political demands are made. The distinction is a principled one, transcending any immediate result.

The charge of partiality is not the only substantial argument against reverse discrimination. In Chapter 5 I suggested that using race, sex, or ethnicity as a way of assigning burdens or benefits seems unfair on

\footnotetext{
${ }^{13}$ (New Haven: Yale University Press, 1975), pp. I32-33.

${ }^{14}$ Regents v. Bakke, 438 U.S. 265, 295, n. 35 (Powell); Fullilove v. Klutznick, roo S.Ct. 2758, 2799, n. 5 (Stewart dissenting), 28 I0-I I, n. 2I (Stevens dissenting).

15 “Toward Neutral Principles of Constitutional Law," Harvard Law Review 73 (November I959):30-34.
} 


\section{Equality under the Constitution}

its face, because of the involuntary, immutable, and irrelevant nature of these traits, whatever race or sex a person happens to be. This is one reason the neutral suspect-classification rule of McLaughlin, Loving, and Frontiero has been so popular-and, I think, underlies Bickel's conclusion about the "lesson of contemporary history."

So the task I have set myself is to argue both that reverse discrimination is principled, and that law may deprive some people, but not others, because of race or sex. This argument confronts certain obstacles, but I think Chapter 4 indicates that the Fourteenth Amendment's legislative history is not paramount among them. In the two miscegenation cases of the 1960 , the Court found in that provision an intent to condemn all racial discrimination, but, in fact, speakers in Congress defended that very kind of law with an argument that contradicts that conclusion. Furthermore, the debates reveal overriding concern with the status of one racial group. Indeed, one scholar has suggested that the principles of the Civil War Amendments were not neutral at all; that the goal was to ensure full equality for blacks; and, implicitly at least, there was nothing wrong with that goal. ${ }^{16}$ That interpretation, of course, would demand the results reached in $\mathrm{Mc}$ Laughlin and Loving as well as in the school segregation cases, but the neutral ban on discrimination does not emerge from the history. The historical evidence is permissive, neither condemning reverse discrimination nor demanding it. Resolution of the issue will have to depend on some other basis.

What is it about race that makes it seem an unfair basis for discrimination? I have devoted some space to this line of argument, but we can put it into sharper focus by considering the viewpoint of the persons affected by such policies. Someone in the position of Marco De Funis, Allan Bakke, or Brian Weber has been denied training that would greatly improve his prospects. Although it would be incorrect to state that this person has been denied benefits because of his race, it is true that his chances have been reduced because of his race. Being white hurt him. And he is no more responsible for being white than others are for being black, Hispanic, or American Indian. Nor does his race have any relationship to his ability to succeed in a training program or a professional school. It is possible to argue that race may have some relationship to a person's value as a doctor or lawyer, if one accepts certain arguments for reverse discrimination, but after all, success in medical or law school is a necessary precondition to becoming

${ }^{16}$ Louis H. Pollak, "Racial Discrimination and Judicial Integrity: A Reply to Professor Wechsler," University of Pennsylvania Law Review 108 (November 1959): I-34. 
a doctor or lawyer. So the case for this applicant has a strong emotional and rational appeal.

But it contains some dissonances. Being white was a disadvantage to De Funis, Bakke, and Weber in one limited instance, but it is hardly a disadvantage in general. On the contrary, any white person alive in this country today has reaped unearned rewards because of race, and a white person's claim to immunity to racially based deprivations must be judged with that fact in mind. Of course, a person cannot help being white, but who would regret it?

That point leads to the paramount difference between invidious and benign discrimination. Other writers, such as Dworkin and Richard Wasserstrom, have made this argument before, but it needs to be developed here. Dworkin insists that the rejected white applicant has no right here "because in his case race is not distinguished by the special character of public insult. On the contrary, the program presupposes that his race is still widely if wrongly thought to be superior to others." Wasserstrom put it this way: "In our culture to be nonwhiteand especially to be black-is to be treated and seen to be as members of a group that is different from and inferior to the group of standard, fully developed persons, the adult white males." Therefore, "it is wrong to think that contemporary affirmative action programs are racist or sexist in the centrally important sense in which many past and present features of our society have been racist or sexist." ${ }^{17}$

The distinction between discrimination against blacks and discrimination against whites is that the former is part of a system that stigmatizes the group and treats its members as inferiors, and the latter is not. This character of public insult is what denies the right to treatment as an equal, and it provides a principle for decision that satisfies the requirements of neutrality. It does no violence to the purposes of the Fourteenth Amendment. And it could have provided a principled basis for the decisions of the I950s and 1960s which instead articulated the notion that any and all racial discrimination was unconstitutional.

\section{Standards and Subjectives}

But the argument cannot stop here. To be a guide to interpretation, a rule must be intelligible and contain objective, reliable criteria for

${ }^{17}$ Dworkin, "Why Bakke Has No Case," p. I4; Wasserstrom, "Racism, Sexism, and Preferential Treatment: An Approach to the Topics," UCLA Law Review 24 (February 1977): 586. 


\section{Equality under the Constitution}

decision making. In his Bakke opinion, Justice Powell criticized the efforts of Justice Brennan and of Judge Mathew Tobriner of the California Supreme Court to develop such a rule as the one toward which I have been working. Brennan distinguished between "racial classifications that stigmatize-because they are drawn on the presumption that one race is inferior to another or because they put the weight of the government behind racial hatred and separatism"-and policies "designed to enable [members of disadvantaged groups] to surmount the obstacles imposed by racial discrimination." Tobriner emphasized the familiar notion of "discrete and insular minorities" who might get special solicitude from government. ${ }^{18}$

It was not the policies these distinctions permit that apparently most troubled Justice Powell. It was rather that he found the concepts of "stigma" and "minority" essentially without meaning. He dealt with "stigma" in a footnote, dismissing it as having "no clearly defined constitutional meaning" and "reflect[ing] a subjective judgment that is standardless." He paid more attention to the differences between "majority" and "minority." These concepts

necessarily reflect temporary arrangements and political judgments....
The white "majority" itself is composed of various minority groups, most
of which can lay claim to a history of prior discrimination at the hands
of the state and private individuals. Not all of these groups can receive
preferential treatment and corresponding judicial tolerance of distinc-
tions drawn in terms of race and nationality, for then the only "major-
ity" left would be a new minority of white Anglo-Saxon Protestants.
There is no principled basis for deciding which groups would merit
heightened judicial solicitude and which would not. ${ }^{19}$

Is Powell right in concluding that no intelligible distinction between advantaged and disadvantaged groups is possible? That "stigma" has no clear constitutional meaning is true, but not particularly significant; neither, after all, did such concepts as "suspect classification" and "clear and present danger" when they first appeared. The way they acquired meaning was through use in a series of cases, and there is nothing to prevent "stigma" from getting similar use. Still, Powell has done us a favor by reminding us that before the concept can be used as a basis for decisions, it is necessary to think about what the term means and about how to recognize the reality that the term describes. This necessity poses a problem, but it is exactly the opposite

${ }^{18} 438$ U.S. $265,357-58 ; 328$; Bakke v. Regents of University of California, 553 P. 2d I I 52 , II 83 (Cal. Sup.Ct. 1976).

${ }^{19} 438$ U.S. 265, 294, n. 34, 295-96. Emphasis supplied. 


\section{When Equal Is Not the Same}

of the one that disturbs Powell: there are not too few standards for judgment, but too many.

"Stigma" has a dictionary definition: "a brand ... a mark of infamy or disgrace ... any mark or label designed to indicate deviation from some norm or standard." This language recalls that of Strauder-"practically a brand upon them"-and a phrase from the Civil Rights Cases-"badges of slavery." 20 "Stigma" is also the title of a well-known book whose sociologist author defines the term as "an attribute which is deeply discrediting." ${ }^{21}$ We know which races this definition applies to; more important, there exist indicators of what we know.

If a stigma is a mark or brand, what constitutes a stigma? One of the best discussions of this issue comes from Richard Wasserstrom:

We know, for instance, that it is wrong, clearly racist, to have racially segregated bathrooms. ... How is this to be accounted for? The answer ... can be discovered through a consideration of the role that this practice played in that system of racial segregation we had in the United States-from, in other words, an examination of the social realities. For racially segregated bathrooms were an important part of that system. And that system had an ideology. ... A significant factor of that ideology was that blacks were not only less than fully developed humans; they were also dirty and impure. They were the sort of persons who could and would contaminate white persons if they came into certain kinds of contact with them.... This ideology was intimately related to a set of institutional arrangements and power relationships in which whites were politically, economically, and socially dominant. The ideology supported the institutional arrangements, and the institutional arrangements reinforced the ideology. The net effect was that racially segregated bathrooms were both a part of the institutional mechanism of oppression and an instantiation of this ideology of racial taint. The point of maintaining racially segregated bathrooms was not in any simple or direct sense to keep both whites and blacks from using each other's bathrooms; it was to make sure that blacks would not contaminate bathrooms used by whites. ${ }^{22}$

In a defense of the Brown decision, Charles L. Black, Jr., described segregation as "a picture of one in-group enjoying full normal communal life and one out-group that is barred from this life and forced into a life of its own." ${ }^{23}$ Black pointed out that in the town of Leeville, for example, the white high school was always Leeville High, while

${ }^{20}{ }_{100}$ U.S. 303, 307-8 (1880); 109 U.S. 3, 20 (1883). Emphasis supplied. See Jones

v. Alfred H. Mayer Corp., 392 U.S. 409, 439, 440 (1968).

${ }^{21}$ Erving Goffman, Stigma (Englewood Cliffs, N.J.: Prentice-Hall, 1963), p. 3.

22 "Racism," p. 592.

23 "Lawfulness of the Segregation Decisions," p. 425. 


\section{Equality under the Constitution}

the black school bore some other name. Hernandez v. Texas, a case decided just two weeks before Brown, gave still more guidelines, and suggested that there can be more than one out-group within a community. This decision, which reaffirmed the principle that the equalprotection clause protected ethnic groups other than blacks, mentioned segregation of public facilities, the extent of participation of a group in community life, and community attitudes as indicators of disadvantage. ${ }^{24}$ It is easy to think of similar indicators, such as income, occupational distribution, and representation in public office.

Feminist literature provides another fruitful source of indicators of stigma and disadvantage. Black's dichotomy of in-group and out-group recalls Simone de Beauvoir's statement that "humanity is male and man defines women not in herself but as relative to him.... He is the Subject, he is the Absolute-she is the Other." ${ }^{25}$ Black's high school illustration sounds rather like the "Mr. and Mrs. John Jones" convention. Scholarly comparisons of race and sex discrimination have directed attention to shared features that may be more subtle. Helen Mayer Hacker's famed article in which she identified high visibility, ascribed attitudes, rationalizations of status, and attitudes of accommodation as characteristics of both blacks and women is one example. ${ }^{26}$

"Stigma," then, does provide a potentially usable and useful standard. If anything, the concept does too much rather than too little. But what about "minority"? There is something disturbing about relying too heavily on this concept; Judge Tobriner, in particular, did not seem to realize that a minority can oppress a majority. But that was not Justice Powell's objection. His two arguments support one another. Had he been more receptive to the concept of stigma, he might have seen ways to distinguish between those groups that qualify for reverse discrimination and those that do not. But even without that help, his argument about the difficulties of distinguishing between minority and majority does not apply to racial groups. They are easy to identify. A final objection to Powell's argument is that nothing in the Constitution prevents the government from deciding to establish reverse discrimination for some disadvantaged groups but not for others. To permit reverse discrimination does not require that it be ex-

\footnotetext{
${ }^{24} 347$ U.S. $475,479-8$ I (1954).

${ }_{25}$ The Second Sex, trans. and ed. H. M. Parshley (New York: Alfred A. Knopf, 1949), p. xvi.

${ }_{26}$ "Women as a Minority Group," Social Forces 30 (October I 951):60. See also, of course, Gunnar Myrdal, An American Dilemma (New York: Harper \& Row, 1944), vol. 2, app. 5 .
} 
tended to all groups that may qualify for it. If anyone were arguing that the Constitution required reverse discrimination, Powell's objection would be a forceful one, but the operative verb is not "require" but "permit." Reverse discrimination is not a right.

To speak of stigmatization and public insult-or, if one prefers, of discreteness and insularity-can therefore provide manageable standards for adjudication. The objective criteria are there. The distinction between in-group and out-group, between empowered and disempowered, need not become bogged down in conceptual difficulties.

But a third question remains. Even if we can distinguish among groups, can we distinguish between invidious and benign policies? This question is particularly troubling and inescapable for the specialist in sex discrimination, who knows all too well that laws intended to be benign can in fact be harmful. Is it not possible that, as even Justice Brennan warned, "programs designed ostensibly to ameliorate the effects of past racial discrimination ... may ... reinforce the views of those who believe that members of racial minorities are inherently incapable of succeeding on their own"? 27 This question echoes a common argument against reverse discrimination, which suggests that it is in fact stigmatizing because it carries a presumption that its beneficiaries have been rewarded on some basis other than their competence. ${ }^{28}$

But for minorities the choice is not between favored treatment and succeeding on one's own; it is often between favored treatment and exclusion. Besides, it is difficult to see how getting a job will create a permanent presumption of inferiority, since, after all, one still has a chance to prove oneself. It is of course true that compensations can become concessions-this is not a trivial problem-but the last decade of sex discrimination cases shows that, although the Court has sometimes had trouble making those distinctions, they can be made.

These cases indicate that reverse discrimination not only can be based on stigmatizing stereotypes, but may have, singly or in combination, any of three effects. First, it may actually compensate for prejudice and oppression. Second, it may harm rather than help the group it reaches. Or third, it may do virtually nothing. Brennan's distinction between laws that stigmatize and laws that compensate is too eitherorish, for there is the third possibility. This group of decisions shows that the old stereotypes are still alive, and contains examples of all three possible effects.

\footnotetext{
${ }^{27}$ Regents v. Bakke, 438 U.S. $265,360$.

${ }^{28}$ See, e.g., Thomas Sowell, Affirmative Action Reconsidered (Washington, D.C.: American Enterprise Institute, 1975), pp. 39-40.
} 
When the sex discrimination cases are grouped logially rather than chronologically, definite patterns emerge. Two social security cases, Weinberger v. Wiesenfeld in 1975 and Califano v. Goldfarb in 1977 , invalidated supposed benefits that in fact were burdens. ${ }^{29}$ Each involved discriminations between widows and widowers. Stephen Wiesenfeld, whose wife died in childbirth, sued to challenge a rule that entitled only widows with minor children to benefits based on a dead spouse's earnings. Leon Goldfarb, a retired man whose wife had worked for many years before her death, was denied benefits under a regulation that restricted them to widowers whose wives had provided at least half their support.

Both regulations appeared to be, and were defended as, discrimination in favor of dependent widows. They contained "a presumption that wives are usually dependent" and would be objectionable for that reason alone. ${ }^{30}$ But there was a graver problem, which the Court saw. The law, it declared in Wiesenfeld,

clearly operates ... to deprive women of protection for their families which men receive as a result of their employment. Indeed ... in this case social security taxes were deducted from Paula's salary during the years in which she worked. Thus, she not only failed to receive for her family the same protection which a similarly situated male worker would have received, but she also was deprived of a portion of her own earnings in order to contribute to the fund out of which benefits would be paid to others. ${ }^{31}$

The same was true of Hannah Goldfarb. So these laws, like the old labor laws and possibly the draft exemption, turn out to be invidious-as well as stereotyping and patronizing. The lesson of Wiesenfeld and Goldfarb is that each case demands, first of all, a determination whether the discrimination involved is benign or invidious.

Three cases involve laws that belong in the "discard" category. The first, Kahn v. Shevin, upheld Florida's $\$ 500$ property tax exemption for widows, a provision that reduced an individual tax bill by about \$ I 5. If the length of the opinion, just over three pages, is any guide, the majority found the case a simple one. Citing government statistics on median earnings of male and female workers, the Court found the law "reasonably designed to further the state policy of cushioning the financial impact of spousal loss upon the sex for which that loss im-

\footnotetext{
${ }^{29} 420$ U.S. $636 ; 430$ U.S. I99.

${ }^{30} 430$ U.S. I $99,217$.

${ }^{31} 420$ U.S. 636,645 .
} 
poses a disproportionately heavy burden." ${ }^{32}$ There are several problems with this reasoning, ${ }^{33}$ but two in particular are relevant here. First, it seems unlikely that this law, which was enacted in 1885 , had any such purpose; it is far more likely that it rested on generalizations about female dependence with which the judges who ruled on earlier laws were at home. Second, a $\$$ I 5 credit does not confer much of a benefit.

The next case was Schlesinger v. Ballard. Here the Court sustained a Navy regulation whose effect was to allow women officers four more years of service before mandatory discharge for want of promotion than male officers got (a provision that was dropped soon after this decision). The Court majority thought this rule, too, was a compensation. Justice Stewart suggested that women officers might need more time than men to pile up comparable records, since they were excluded from combat and most sea duty. The dissenters' response to this argument was devastating. Justice Brennan showed that the regulation was part of a scheme that, far from compensating women officers, severely restricted their opportunities, and pointed out that male and female line officers do not compete for promotion. ${ }^{34}$ The benefits conferred on women by this law were as illusory as those in Florida's tax exemption.

Nearly two years passed between Ballard and the next similar decision, Craig v. Boren, the 3.2 percent beer case. No one ever claimed a compensatory purpose for this discrimination; it is reverse discrimination, however, since it does benefit the previously disadvantaged group. The Court found "an unduly tenuous 'fit'" between the state's interest in traffic safety and an association so limited and arbitrary as that between young manhood and drunk driving. ${ }^{35}$ The importance of Craig lies in the constitutional rule it pronounced on sex discrimination, which I discussed in Chapter 5. This rule reappears in Brennan's Bakke opinion as demanding "an important and articulated purpose" for reverse discrimination, whether racial or sexual. ${ }^{36} \mathrm{My}$ own analysis of this group of cases convinces me that, at least as far as it goes, Brennan's conclusion is correct.

A test for reverse discrimination must distinguish between legitimate and illegitimate policies and among compensation, concession,

\footnotetext{
${ }^{32} 4$ I 6 U.S. 35 I, 355 (1974); see Ruth Bader Ginsberg, "Gender and the Supreme Court," Supreme Court Review, 1975, pp. I, 4.

${ }^{33}$ Baer, "Sexual Equality," p. 480.

${ }^{34} 4$ I 9 U.S. 498, 508-9, 5 I I-I 7 (1975).

${ }^{35} 429$ U.S. 190, 202 (1976).

${ }^{36} 438$ U.S. $265,36 \mathrm{I}$.
} 
and trivia. Like most rules, this one works best in the situation in which it originated: a case such as Craig, where only the most dubious relation existed between the law at issue and any objective. Kahn and Ballard are similar cases, and in each the rule would dictate the opposite result. The Craig rule was actually applied in two important reverse sex discrimination cases. These are more difficult cases than any of the preceding ones; the laws not only granted tangible benefits, but had a clear connection to serious governmental purposes. These cases show that, while the Craig rule is not self-applying, the inevitable problems can be solved. The rule does permit the crucial distinctions.

A 1979 case, Orr v. Orr, overturned Alabama's sex-specific alimony law. Its roots in sexist stereotypes- "the state's preference for an allocation of family responsibilities in which the wife plays a dependent role" ${ }^{37}$-are obvious, but the relationship of these roots to the law itself is not altogether clear. At this point we need to consider both the importance of the law's end and the relationship between ends and means.

To require an "important" purpose is a more stringent rule than to demand a "legitimate" one, but for an end to be important it must at least be legitimate. The alimony law appears on its face to be designed to protect needy ex-wives. Indeed, the Alabama court insisted that the law was enacted for "the wife of a broken marriage who needs financial assistance." ${ }^{38}$ This end is inseparable from an assumption of female dependence and financial inadequacy. This notion arises from and reinforces society's pattern of sexual stigmatization by which sex becomes a proxy for inferiority. Such legislation, as Brennan cogently argued in Bakke and Frontiero, is inherently illegitimate. This point becomes clearer if we imagine a law that provided some similar kind of benefit, upon individual qualification, only to blacks. Although blacks are indeed more likely than whites to be poor, the assumption that only blacks, and any black, may be incapable of self-support is patently racist.

Suppose, however, that Alabama's purpose was not to protect wives (despite what the state's own court said), but to protect spouses, and that, to paraphrase Goldfarb, the state coupled with this aim a presumption of wifely dependence. Justice Brennan apparently thought this was the true situation: "a legislative purpose to provide help for needy spouses, using sex as a proxy for need." If so, the ends are sex-

${ }^{37} 99$ S.Ct. I I 02 , I I I I (I 979) (Brennan).

${ }^{38}$ Orr v. Orr, 35 I So. 2d, 905 (Ct. Civ. App. Ala. 1978); cited, 99 S.Ct. I I02, I I I 2. Emphasis supplied. 
neutral-and concededly valid-but the means are sex-specific. The same sexist presumptions may exist as before, but at this point the usual secondary justification for these laws, administrative convenience, has to be considered. Even this interpretation has not exhausted the possibilites. Alternatively, the law might compensate "women for past discrimination during marriage, which assertedly has left them unprepared to fend for themselves in the working world following divorce." ${ }^{39}$ This is a sex-specific end, but, despite patronizing undertones, it too closely resembles benign discrimination to be casually dismissed as a sexist one.

The Court found it unnecessary to resolve either of these issues. The opinion found no valid reason for using sex as a proxy for either need or disadvantage. Since an individual hearing was always required before a judge could award alimony, such wives could be helped even with a sex-neutral policy, with little additional burden on the state. Thus even the problem of administrative convenience is illusory.

In an academic context, the compensation argument deserves more consideration than the Court gave it. A good analogy here is Ballard. Preference for women in regard to military tenure turned out to be part of a pattern of negative discrimination rather than true compensation. (If a third analogy is forgivable, it was rather as if universities gave female junior faculty members extra probationary time while simultaneously imposing heavier teaching loads on them or a ceiling on their publications.) Some of the "discrimination during marriage" of which Justice Brennan spoke consists of legally imposed or ratified restrictions on wives, such as domiciliary dependence and domestic duties. The law of marriage and divorce is notoriously sexist and traditional; it is highly unlikely that alimony was ever designed as a form of compensation.

Even though Orr v. Orr itself did not demand resolution of some of these problems, future cases probably will, and this discussion shows the usefulness of the Craig rule. It does suggest, however, an amendment that may be necessary: not only must a law meet the test of substantial relation to important purpose, but the purpose must be one that cannot be fulfilled by sex-neutral or race-neutral means. Thus the alimony law, like Florida's tax exemption, would fall because its legitimate ends can be achieved by neutrally written laws.

Of the relevant cases, only Califano v. Webster remains. This is the only case that involves true benign discrimination. Webster involved a rule whereby old-age insurance benefits depend on a worker's average

${ }^{39} 99$ S.Ct. I I O2, I I I 2. 


\section{Equality under the Constitution}

monthly wage earned during the years (reduced by five) during which wages were highest. Until 1972, when the scheme was equalized, a woman worker could exclude three more lower earning years from her average than a man could. In a per curiam opinion in 1977, the Court applied the three-month-old Craig rule to sustain the defunct provision. Far from being a product of obsolete generalizations about ability or dependence, the scheme "operated directly to compensate women for past economic disadvantage." 40

The provision was not designed to alleviate poverty, using sex as a proxy for poverty. Its purpose was rather to rectify a certain kind of economic disadvantage: sex discrimination in earnings. Sex was not a proxy for anything. Ample evidence exists of the disparity between men's and women's earnings; this disparity transcends class, race, occupation, education, and all other relevant factors. Virtually all women (whether deliberately or not) have been underpaid because they are women. The importance of the law's purpose is demonstrable, and by its nature that purpose can be achieved only by sex-specific means. The only way to compensate for sex discrimination is to provide benefits on the same basis.

Webster supplies a good analogy to Bakke. Race has limited educational opportunities as surely as gender has restricted earnings. These disadvantages have persisted for a long time; even if proof is lacking that they have been imposed willfully, they have been imposed. Each policy helped make up for the past inequalities, and afforded real, not illusory, benefits to the groups involved. If the social security provision is constitutional, there is every good reason why preferential admissions should be.

These cases have vindicated the fears Justice Brennan expressed in $B a k k e$. Too ready acceptance of reverse discrimination would be dangerous. Even recent laws can reinforce negative stereotypes, hurt rather than help, be part of a system of rules that is in fact invidious, or be so trivial as to verge on banality. Reverse racial discrimination may present fewer opportunities than sex discrimination for this type of legislation, given prevailing climates of opinion, but if we treat race and sex discrimination with equal seriousness, we must develop rules that avoid these dangers as far as possible.

Consistently with the history and spirit of the Fourteenth Amendment, we can generalize from race and sex to other attributes. To consign people to an inferior position in society, to disempower them, to insult and stigmatize them is to deny them the right to treatment as

${ }^{40} 430$ U.S. 313,318 (1977). 
equals. But to discriminate against a member of a favored group in order to bring disfavored groups to full equality does not relegate the person to what has been the status of racial minorities or even of women, and therefore does not violate that fundamental right. Invidious racial and sexual discriminations should, as Brennan noted in Bakke, be "invalid without more" ${ }^{41}$ - not suspect, invalid. That concept would remove the disgrace of Hirabayashi and Korematsu and prevent any similar decisions in the future. But benign racial and sexual discriminations are recognizable as such, and do not stigmatize, and should be permitted.

\section{Nagging Questions}

But when, and under what circumstances, should reverse discrimination be permitted? Brennan, borrowing from Craig v. Boren, has suggested a test here: that "an important and articulated purpose ... must be shown." ${ }^{42}$ Do we want to accept any such discrimination that satisfies this test? Certainly such a case as McDonald is worrisome, though the result is welcome. That a black person should go unpunished for misconduct that gets white workers fired is inexcusable. But it is helpful to think about why this situation is so disturbing. In such a case, several workers have committed an act for which each is responsible; all exercised individual choice, and all were guilty of wrongdoing. This is not, therefore, a typical case of race discrimination. It is not unlike Senator Howard's example of the black man who is hanged for a crime for which a white man is not hanged. Individual responsibility, which is exactly what is absent from most cases of race discrimination, was present, and was discounted.

In McDonald, two workers were punished and a third was not. That decision, in itself, is not necessarily wrong. When several people commit the same offense, they are often punished differently. Various reasons may be offered, including such factors as exculpatory circumstances and prior records. But all these factors relate to individual responsibility, motive, or intent. Punishment for wrongdoing is a distinct kind of policy; rather like course grading, it depends on individual responsibility in ways that other decisions do not. The nexus between wrongdoing and punishment is tighter than that between test scores and medical school. Punishment depends on a person's behav-

${ }^{41} 438$ U.S. $265,358$.

${ }^{42}$ Ibid., p. 36 I. See 429 U.S. 190 (1976). 
ior in a specific situation, governed by specific rules known to both the punished and the punisher. It is a special case.

There are other situations in which reverse discrimination would be disturbing. A thread that runs through discussions of this issue is the fear expressed by Justice Brennan in Bakke that these programs may reinforce racist notions. We have seen some examples of allegedly preferential treatment for women which reinforce sexist notions, and it is possible to imagine racial analogies. Suppose, for example, that a law provided some sort of financial benefit, upon individual qualification, only to blacks. It is true, of course, that blacks are more likely than whites to be poor. But an assumption that only blacks can be, and any black may be, incapable of self-support is clearly racist. It harms both those included in and those excluded from the benefits. This policy may sound fanciful as an example of race discrimination, but if we think of sex discrimination, it recalls Orr v. Orr. Such policies, whether designed for women or for racial minorities, are objectionable because they use sex or race as a proxy for a factor such as need, which is not only poorly related to these attributes, but related to them in a patronizing and insulting way.

Such a law differs from classic reverse discrimination in yet another important respect. It excludes individuals entirely from a benefit on the basis of race or sex. The deprivation is absolute. It is as if a professional school reserved all of its places for minorities, not just sixteen out of a hundred, as Davis did. Suppose, just to make the hypothetical case more interesting, that this school is not one of several within a large urban area but one that is relatively isolated, as UC Davis is. Since not everyone is free to move in order to go to medical school, such a policy could effectively prevent some people from attending at all. This is too severe a deprivation to be based on race or sex alone. (Howard, Meharry, and the Women's Medical College of Pennsylvania would not be vulnerable to this objection, since in their prime they were not only limited to blacks or women but were in effect the only institutions open to them on an equal basis. None of them is now so limited.) The character and severity of the deprivation have to be considered.

In at least three situations, then, reverse discrimination would not be acceptable. Only the second, the "black alimony" case, can reasonably be said to involve any sort of stigmatization, to imply defects in those ostensibly favored. The other two cases could survive the Craig test of important and articulated purpose. But the harm they inflict on the majority is too great. Total exclusion has something in common with $M c D o n a l d$. To punish differentially, or to bar people from edu- 
cation, training, or employment, does worse damage than to reduce their chances to compete for limited resources.

The two-tier equal-protection model does recognize similar distinctions of degree, but its rigid dichotomy between ordinary interests and "fundamental rights" will not help solve the problem. Getting into medical school is not a fundamental right, nor is escaping punishment when others escape it (although, if McDonald had involved criminal prosecution, that possibility could not easily be dismissed). This discussion recalls Justice Marshall's dissent in Rodriguez, where he rejected the two-tier model in favor of concentration on "the character of the classification in question, the relative importance to individuals in the class discriminated against of the governmental benefits that they do not receive, and the asserted state interests in support of the classification." ${ }^{43}$ Some hierarchy of interests and claims has to be built into equal-protection litigation.

\section{Conclusion}

There are principled bases for distinguishing between malign and benign discrimination; between the advantaged and disadvantaged; between acceptable and unacceptable deprivations. We need not be hypocrites in order to defend reverse discrimination. Such a defense can rest on distinctions stronger than my ox versus your ox. What constitutional arguments in favor of reverse discrimination force us to do is not to reject all principle but to reexamine the landmark cases of the last thirty years. The principle that some of them articulatedthat all racial discrimination is illegitimate-is not compatible with reverse discrimination. But this chapter and the last have shown that that principle was not necessary for those results.

The reverse discrimination cases, like the rulings examined in Chapter 5, show how the Supreme Court has constricted the Constitution's guarantee of equality. The decisions focus not on the foundations of this guarantee but on the traits that are the bases for classification. A broad guarantee of equality is read as a proscription of race discrimination. This construction is both less and more than what the constitutional language and history imply. As we have seen, Section I of the Fourteenth Amendment is not phrased in terms of race. There is no powerful reason to conclude that its scope is limited to race discrimi-

${ }^{43} 4$ I I U.S. I, 99 (1973). Emphasis supplied. 


\section{Equality under the Constitution}

nation. Nor is there any powerful reason to read the Constitution as forbidding all racial discrimination, whomever it helped.

Supposedly "neutral" discriminations are indeed premised on notions of inferiority. But discriminations in favor of those groups that have been stigmatized, oppressed, and insulted are designed to bring these groups to full equality. Therefore, they are in accord with the Constitution, and there is no persuasive legal argument against them. They may not always be necessary; specific plans, certainly, may be unwise; and they may not achieve their purpose. It is possible, as times and attitudes get harder, that we shall see fewer and fewer of them. But these considerations are not reasons to declare such discriminations unconstitutional, and thus to frustrate efforts to fulfill the promise of the Fourteenth Amendment.

The next three chapters represent a change in focus. Now I shall be concerned not with race and sex but with age, disability, and sexual orientation. The issue of age discrimination may be recent, but the fact is very old, and legal frameworks exist for dealing with it. In the last two areas the problems go beyond questions of discrimination. The handicapped and homosexuals are the targets of discrimination, but that is not all they are subjected to. Not only will I get further and further away from traditional legal categories, but my scope will widen beyond equal protection and the Fourteenth Amendment.

I shall still be concerned with cases, but in none of the next three chapters do I attempt a comprehensive overview of the relevant case law. Nor will I confine myself to cases. Because these are new demands, some of the people who will figure prominently in the next chapters come from 60 Minutes and the New York Times rather than United States Reports and the Federal Reporter. But here again I shall be concerned with what these issues can teach us about equality under the Constitution. 